\title{
Metode Jarimatika Berbasis Role Play dalam Meningkatkan Pembelajaran Matematika
}

\author{
Siti Asfiyah ${ }^{1 *}$, Peni Nur Hidayati ${ }^{1}$, Siti Nok Chalimah ${ }^{1}$ \\ ${ }^{1}$ MI Ma'arif Dukuh, Salatiga, Jawa Tengah \\ "E-mail: pennynurhidayati@gmail.com
}

\begin{abstract}
Abstrak
Selama ini siswa mengalami kesulitan dalam menghitung perkalian. Tak sedikit siswa yang membutuhkan waktu lama untuk menghitung hasil perkalian tersebut. Penggunaan jarimatika berbasis role play diharakan bisa membantu siswa yang mengalami kendala dalam proses pembelajaran, terutama dalam kegiatan menghitung. Penggunaan metode jarimatika berbasis role play bertujuan untuk mengetahui peningkatan hasil belajar materi perkalian pada mata pelajaran matematika dengan metode jarimatika berbasis role play pada siswa kelas II SDN Kesongo 01 Tuntang Semarang Tahun Pelajaran 2017/2018. Penelitian ini termasuk penelitian tindakan kelas (PTK) yang menerapkan metode pengumpulan data berupa tes, observasi, serta dokumentasi. Adapun analisis data yang dilakukan yaitu dengan membandingkan nilai hasil belajar setiap siklus yang berpatokan pada KKM SDN Kesongo 01 yaitu 75 dengan Ketuntasan Klasikal 85\%. Hasil penelitian ini memperihatkan bahwa penerapan metode jarimatika berbasis role play dapat membantu meningkatkan hasil di siklus belajar siswa. Hal ini terlihat dari bukti hasil pra siklus, rata-rata siswa mulai 64 menjadi 63,33 dan 2 meningkat menjadi 92,08. Dari pra siklus ke sikus I presentase ketuntasan siswa meningkat dari $25 \%$ menuju $37,5 \%$ dan di siklus II lebih meningkat lagi menjadi 95,83\%. Kesimpulan dari penelitian ini adalah metode jarimatika berbasis role play dapat meningkatkan hasil belajar matematika. Selain pengetahuan siswa yang meningkat, keaktifan, kerja sama dan rasa tanggung jawab mereka juga meningkat.
\end{abstract}

Kata kunci: Jarimtika, Matematika, Metode, Role Play.

\section{PENDAHULUAN}

Istilah pembelajaran dalam dunia pendidikan merupakan serangkaian kegiatan yang didesain agar memungkinkan proses terjadinya belajar pada siswa. Desain pembelajaran ini berisi usaha yang disengaja, dengan tujuan dan adanya kendali kepada siswa agar siswa belajar dan menjadikan perubahan yang bisa menetap pada dirinya (Rusmono, 2014).

Secara etimologis, belajar sendiri memiliki makna proses seseorang untuk daat melewati bermacam-macam kompetensi, keterampilan dan sikap (Baharudin dan Wayuni: 2008). Sedangkan menurut Slamento istiah belajar merupakan suatu proses perubahan yaitu perubahan dalam tingkah laku keseharian sebagai hasil dari interaksi dengan lingkungan untuk memenuhi kebutuhan hidupnya. (Slameto, 1991).

Matematika adalah salah satu pembelajaran yang dibutuhkan baik di sekolah maupun di dalam kehidupan di masyarakat. Belajar matematika sama pentingnyadengankebutuhankomunikasi manusia sebagai makhluk sosial yang 
butuh orang lain. Kebutuhan tersebut mau tidak mau mengharuskan seseorang mengenal matematika dengan baik supaya dapat hidup di tengah masyarakat dengan baik pula. Dalam mendorong semangat belajar anak-anak agar bisa menguasai pembelajaran matematika, pemerintah telah memasukkan pembelajaran matematika ke dalam ujian yang penting untuk kelulusan yang menjadi bukti hasil belajar siswa.

Hasil belajar siswa juga dapat dilihat dari sembilan wujud perubahan, antara lain: kebiasaan, keterampilan, pengamatan, berpikir asosiatif dan daya ingat, berpikir rasional dan kritis, sikap, apresiasi, tingkah laku efektif. Hasil belajar siswa juga dapat dilihat dari adanya kemampan seseorang untuk melakukan sesuatu secara baik (Sriyanti, 2011).

Selama pembelajaran matematika berlangsung, siswa memerlukan alat bantu berupa media dan alat peraga yang membantu memperjelas apa yang akan diajarkan oleh guru sehingga lebih cepat dipahami dan dimengerti oleh peserta didik.

Setiap jenis metode pembelajaran yang digunakan memiliki kelebihan dan kelemahan sendiri-sendiri. Terkadang, guru dan pengajar tidak hanya menggunakan satu macam metode saja, mereka juga bisa mengkombinasikan penggunaan berbagai metode pembelajaran yang sampai saat ini masih banyak digunakan dalam proses belajar mengajar. Di dalam metode pengjaran terdapat bermacam-macam metode. Semisal tanya jawab, ceramah, diskusi, kerja kelompok, role play, latihan dan simulasi. (Kurniasih dan Sani, 2017)

Siswa usia SD masih belajar pada thapan belajar Konkrit, dimana tahapan belajar anatara lain: tahapan konkret, semi konkret, semi absrtrak, dan selanjutnya abstrak. Dalam pembelajaran matematika, setiap konsep yang abstrak dan baru dielajari siswa perlu segera diberi penguatan, agar mesuk ke dalam otak dan bertahan lama dalam memori siswa, sehingga akan terpatri erat dalam cara berfikir dan tindakannya (Heruman, 2010).

Berdasarkan hasil pengamatan yang dilakukan peneliti di SD Negeri Kesongo 01 Tuntang Semarang melalui wawancara dengan guru kelas II ditemukan beberapa masalah yaitu: masih ada beberapa anak yang kurang fokus selama pelajaran berlangsung. Ada yang suka ngalamun, diam tapi tidak memperhatikan dan masih terdapat anak yang tidak fokus pada pembelajaran yang sedang berlangsung. Kurangnya keterlibatan siswa dalam proses pembelajaran dan kurangnya pemahaman siswa dengan materi yang sedang disampaikan oleh guru, yang mengakibatkan tujuan pembelajaran kurang tercapaimaksimal. Masih ada siswa yang merasa kesulitan untuk menyerap informasi yang disampaikan oleh guru karena masih kurangnya variasi metode dalam pembelajaran yang digunakan. Permasalahan-permasalahan yang muncul dapat dilihat dari data nilai ulangan harian matematika yang masih banyak siswa belum tuntas. Berdasarkan data siswa kelas II SDN Kesongo 01 berjumlah 24 siswa dan hanya 25\% (6 siswa) yang 
sudah mencapai KKM, sedangkan 75\% (18 siswa) belum mencapai KKM.

Berdasarkan faktor permasalahan tersebut, peneliti berdiskusi dengan guru kelas II SDN Kesongo 01 mengenai metode yang dapat mengatasi permasalaan tersebut. Dengan adanya penggunaan metode yang sekiranya sesuai dan menarik diharapkan mampu meningkatkan hasil belajar setiap siswa. Dalam hal ini, peneliti menawarkan untuk menggunakan metode jarimatika berbasis role play sebagai solusi dalam mengatasi masalah pembelajaran matematika materi perkalian di kelas II SDN Kesongo 01 Tuntang Semarang Tahun Pelajaran 2017/ 2018.

Metode jarimatika atau jari tangan ini sudah dikembangkan sejak ribuan tahun yang lalu. Orang zaman dahulu menggunakan jari untuk menghitung benda-benda yang dimilikinya dan hitungannya masih dalam jumlah yang terbatas yaitu 1, 2 dan 3. (Prasetyo, 2009:15)

Role play atau bermain peran yaitu peserta didik mengeksplorasi hubungan manusia dalam situasi permasalahan yang sedang dihadapi, kemudian mendiskusikannya. Bermain peran dapat meningkatkan ingatan peserta didik dan harapannya ilmu yang disampaikan oleh guru dapat bermakna. (Akbar, 2013: 53)

Berdasarkan permasalahan dan latar belakang tersebut, penulis melakukan penelitian yang berjudul Peningkatan Hasil Belajar Matematika Materi Perkalian dengan Metode Jarimatika Berbasis Role play pada Siswa Kelas II SDN Kesongo 01 Kecamatan Tuntang Kabupaten Semarang Tahun Ajaran 2017/2018.

\section{METODE}

Metode sendiri adalah cara kerja yang bersistem untuk membantu memudakan pelaksanaan suatukegiatan guna mencapai tujuan tertentu. Sedangkan jarimatika singkatan dari jari dan aritmatika yang memiliki arti berhitung dengan jari tangan (Prasetyono, 2010).

Role play dalam bahasa Indonesia artinya yaitu bermain peran. Dalam arti luas yaitu metode yang melibatkan partisipan dan pengamat pada situasi permasalahan yang ada, memahami, memecahkan problem tersebut dengan melibatkan siswa.

Metode role play (bermain peran) adalah metode yang membutuhkan interaksi antara dua siswa atau lebih tentang suatu topik atau situasi. Setiap siswa melakukan perannya masingmasing sesuai tokoh yang akan ia perankan. Mereka berinteraksi dengan sesama teman dengan melakukan peran terbuka (Hamdani, 2011:163).

Jadi yang dimaksud dengan judul skripsi ini adalah upaya meningkatkan hasil belajar siswa materi perkalian melalui metode pembelajaran jarimatika berbasis role play pada siswa kelas II SDN Kesongo 01 Kecamatan Tuntang Kabupaten Semarang.

Penelitian ini dirancang menggunakan Penelitian Tindakan Kelas (PTK). Peneliti menggunakan penelitian tindakan kelas ini dengan tujuan untuk meningkatkan hasil belajar materi perkalian mata pelajaran Matematika dengan menggunakan metode jarimatika berbasis role play. Selama penelitian berlangsung, peneliti 
berperan sebagai pengamat, sedangkan proses pembelajaran dilakukan guru kelas dan siswa.

Adapun subjek dalam penelitian ini merupakan guru kelas II dan siswa kelas II SDN Kesongo 01 Tuntang Semarang Tahun Pelajaran 2017/2018 dengan jumlah total siswa 24 dengan 16 siswa laki-laki dan 8 siswa perempuan.

Penelitian tindakan kelas terdiri dari empat tahapan yaitu perencanaan, pelaksanaan, pengamatan dan refleksi.

Perencanaan tindakan penelitian merupakan tindak lanjut dari pra perencanaan yang telah ditentukan yaitu berisi penyusunan proposal penelitian, menentukan tema dan judul, merumuskan masalah, tujuan, manfaat penelitian, menyusun landasan teori, menyusun kajian pustaka, merumuskan hipotesis penelitian, menentukan subyek, lokasi, metode penelitian. Peneliti dalam tahap perencanaan bertugas menetapkan keputusan, kegiatan dan langkah-langkah yang akan dilaksanakan di kemudian hari dalam rangka mencapai tujuan agar lebih efektif (Saputo, 2017).

Perencanaan yang peneliti lakukan meliputi hal-hal yang dilakukan sebelum pelaksanaan tindakan. Adapun kegiatan yang dilakukan pada tahap perencanaan adalah: 1) membuat RPP dengan metode jarimatika berbasis role play; 2) menyiapkan media yang akan digunakan selama kegiatan pembelajaran; 3) menyiapkan lembar observasi yang bisa digunakan pada setiap proses pembelajaran; 4) mempersiapkan soal yang akan diberikan pada setiap siklus;
5) menyiapkan soal untuk role play. Adapun teknik pengumpulan data melalui beberapa tahap diantarannya: tes, observasi. Dan dokumentasi.

Penelitian ini dilaksanakan berdasarkan dua pengamatan yaitu pengamatan selama proses pembelajaran berlangsung di dalam kelas dan hasil evaluasi siswa setelah pembelajaran berlangsung.

Selama penelitian ini berlangsung, peneliti melaksanakan penelitian pada siswa kelas II SDN Kesongo 01 Kecamatan Tuntang Kabupaten Semarang tahun pelajaran 2017/2018 dengan menerapkan metode jarimatika berbasis role play pada materi perkalian. Dalam proses penilaian pada penelitian ini, peneliti menggunakan Kriteria Ketuntasan Klasikal yaitu 85\% dari jumlah seluruh siswa dengan berpedoman pada Kriteria Ketuntasan Minimal (KKM) yang telah ditetapkan oleh SDN Kesongo 01 yaitu 75. Berdasarkan hasil belajar pada pembelajaran matematika, peneliti melakukan evaluasi dari hasil belajar dengan tes formatif yang telah dilaksanakan setelah pembelajaran selesai pada siklus I dan siklus II

\section{HASIL DAN PEMBAHASAN}

Siklus I dilaksanakan pada tanggal 26 April 2018 di kelas II dengan jumlah siswa 24. Proses pembelajaran berlangsung selama 70 menit $(2 \times 35$ menit). Materi yang diajarkan pada siklus I adalah perkalian sederhana. Adapun hasil pengamatan yang dilakukan pada siklus I menunjukkan siswa lebih tertarik dan bersemangat dalam mengikuti proses pembelajaran 
dengan metode jarimatika berbasis role play meskipun masih terkendala bahwa belum semua siswa ikut aktif selama proses pembelajaran. Nilai rata-rata siswa pada siklus I mencapai 63,33. Siswa yang sudah mencapai Kriteria ketuntasan Minimal (KKM) sebanyak 9 siswa (37,5\%). Sedangkan siswa yang belum mencapai Kriteria Ketuntasan Minimal (KKM) sebanyak 15 siswa (62,5\%).

Hasil belajar siswa dalam siklus I secara klasikal belum berhasil karena hanya ada 9 siswa (37,5\%) yang seharusnya dapat mencapai 85\% dari jumlah keseluruhan siswa. Yang menjadi indikator keberhasilan secara klasikal belum tercapai 85\% sesuai harapan dari jumlah keseluruhan siswa yang ada, jadi harus dilakukan siklus selanjutnya yaitu siklus II pada waktu yang telah ditentukan.

Siklus II dilaksanakan pada tanggal 3 Mei2018 di kelas II dengan jumlah siswa 24. Pembelajaran berlangsung selama 70 menit $(2 \times 35$ menit). Materi pokok yang diajarkan pada siklus II adalah perkalian dengan soal cerita. Hasil pengamatan yang dilakukan pada siklus II menunjukkan bahwa siswa semakin bersemangat dalam mengikuti pembelajaran dengan metode jarimatika berbasis role play.

Dari hasil tes siklus II yang telah dilakukan menunjukkan adanya peningkatan hasil belajar siswa yaitu sebanyak 23 siswa dapat mencapi KKM dengan presentase 95,83\% hasil ini telah melampaui KKM klasikal yang diharapkan. Oleh sebab itu, pembelajaran matematika kelas II materi perkalian dengan menggunakan metode jarimatika berbasis role play telah berhasil dan pelaksanaan penelitian dihentikan pada siklus II saja.

Berdasarkan analisis data dalam penelitianmateriperkalian,makadiperoleh hasil rekapitulasi data peningkatan hasil belajar siswa. Rekapitulasi data hasil belajar siswa dapat dilihat pada tabel 1 bawah ini.

Tabel 1. Rekapitulasi Hasil Belajar Siswa Siklus I dan II

\begin{tabular}{cclcc}
\hline Siklus & $\begin{array}{l}\text { Rata- } \\
\text { rata }\end{array}$ & $\begin{array}{l}\text { Kate- } \\
\text { gori }\end{array}$ & Jumlah & $\begin{array}{l}\text { Persen- } \\
\text { tase }\end{array}$ \\
\hline I & 63,33 & Tuntas & 9 siswa & $37,5 \%$ \\
& & Tidak & 15 & $62,5 \%$ \\
& & Tuntas & siswa & \\
II & 92,08 & Tuntas & 23 & $95,83 \%$ \\
& & \multicolumn{3}{c}{ siswa } \\
& & Tidak & 1 siswa & $4,17 \%$ \\
& & Tuntas & & \\
\hline
\end{tabular}

Dari data siklus I di atas menunjukkan hasil belajar siswa yang tuntas sebanyak 9 siswa $(37,5 \%)$ dan siswa yang belum tuntas sebanyak 15 siswa. Sedangkan siklus II jumlah siswa yang tuntas sebanyak 23 (95,83\%) dan hanya $1(4,17 \%)$ siswa saja yang belum tuntas. Dari perolehan nilai evaluasi siklus II telah mencapai nilai ketuntasan klasikal yakni di atas 85\%. Peningkatan hasil belajar ini dapat dilihat dari grafik peningkatan hasil belajar siswa seperti pada gambar 1 berikut.

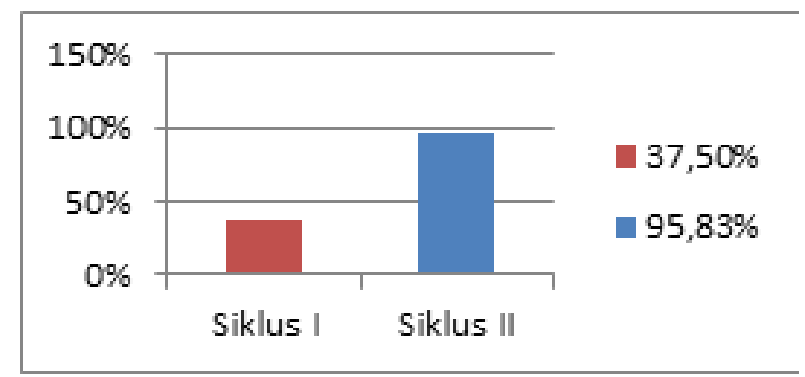

Gambar 1. Grafik Hasil Belajar Siswa Siklus I-II 


\section{SIMPULAN}

Berdasarkan hasil penelitian di atas dapat diambil kesimpulan bahwa penerapan metode pembelajaran jarimatika berbasis role play dapat meningkatkan hasil belajar matematika materi perkalian pada siswa kelas II SDN Kesongo 01 Kecamatan Tuntang Kabupaten Semarang tahun pelajaran 2017/2018. Hasil penelitian tersebut dapat dibuktikan dari hasil presentase pra siklus sebelum penerapan metode jarirmatika berbasis role play yaitu 25\% (6 anak tuntas). Terjadi peningkatan pada siklus I yaitu 37,5\% (8 anak tuntas). Karena ketuntasan klasikal belum tercapai, maka peneliti melakukan siklus selanjutnya yang hasilnya lebih meningkat dari sebelumnya yaitu 95,83\% (23 anak tuntas). Hal ini mempengaruhi nilai rata-rata kelas yang juga meningkat dari siklus I yang hanya 63,33 dapat meningkat di siklus II yaitu 92,08. Penelitian berhenti di siklus II karena dianggap sudah mencapai target ketuntasan klasikal yaitu 85\% dari jumlah keseluruhan siswa di kelas.

\section{DAFTAR PUSTAKA}

Akbar, Sa'dun. (2013). Instrumen Perangkat Pembelajaran. Bandung: PT Remaja Rosdakarya.

Baharudin dan Wayuni, Esa Nur. (2008). Teori Belajar \& Pembelajaran. Jogjakarta: Ar-Ruzz Media.

Hamdani. (2012). Strategi Belajar Mengajar. Bandung: Pustaka Setia

Heruman. (2010). Model Pembelajaran Matematika di Sekolah Dasar. Bandung: Remaja Rosdakarya.

Kurniasih I., dan Sani. (2017). Lebih Memahami Konsep \& Proses
Pembelajaran (Implementasi dan Praktek Dalam Kelas). Surabya:Kata Pena.

Prasetyono D.S., dkk. (2010). Pintar Jarimatika: Bimbingan Cepat dan Tepat Hanya dengan Jari Plus Metode Hensis (HS \& Simulasi Hitungan). Yogyakarta: Diva Press.

Rusmono. (2014). Strategi Pembelajaran dengan Problem Bassed Learning Itu Perlu. Bogor: Ghalia Indonesia.

Slameto. (1991). Belajar dan Faktor-faktor yang Mempengaruhinya. Jakarta: Rineka Cipta.

Sriyanti, Lilik. (2011). Psikologi Belajar. Salatiga: STAIN Salatiga Press.

\section{PROFIL SINGKAT}

Penulis yang pertama bernama Siti Asfiyah yang lahir di Salatiga, tanggal 9 Juli 1996. Penulis mengenyam pendidikan muli dari SDN Kesongo 2, SMPN 4 Salatiga, SMAN 3 Salatiga, S1 di IAIN Salatiga dan sedang menyelesian pendidikan S2 di IAIN Salatiga. Saat ini juga mengajar di MI Ma'arif Dukuh Salatiga.

Penulis ke-2 bernama lengkap Peni Nur Hidayati yang lahir di Kabupaten Semarang. Beliau pernah mengenyam pendidikan di MI Ma'arif Kebumen Banyubiru, SMPN 2 Banyubiru, SMKN 1 Salatiga, S1 di IAIN Salatiga, dan alumni S2 di IAIN Salatiga. Saat ini menjadi pengajar di MI Ma'arif Dukuh salatiga.

Penulis ke-3 bernama lengkap Siti Nok Chalimah yang lahir di Kabupaten Pekalongan. Beliau pernah mengenyam pendidikan di SDN 1 Kedungwuni, MTsN Buaran Pekalongan, MA Manbaul Ulum Jakarta, S1 IAIN Walisongo Semarang dan alumni S2 di IAIN Salatiga. Saat ini menjadi pengajar di MI Ma'arif Dukuh salatiga. 